\title{
HUBUNGAN ANTARA SELF EFFICACYDAN DUKUNGAN SOSIAL ORANGTUA DENGAN SELF REGULATED LEARNING SERTA IMPLIKASINYA TERHADAP BIMBINGAN DAN KONSELING
}

\author{
Ade Chita Putri Harahap, Neviyarni S, Daharnis \\ Penulis adalah Dosen Sekolah Tinggi Keguruan dan Ilmu Pendidikan (STKIP) \\ Perguruan Tinggi Budidaya Binjai
}

\begin{abstract}
This research was based on how important to increase the students self regulated learning. Self efficacy and parent social support were the factors assumed to affect the self regulated learning. The purpose of this research were to describe: (1) self efficacy, (2) parent social support, (3) self regulated learning, (4) the relationship between self efficacy with self regulated learning, (5) the relationship between parent social support with self regulated learning, and (6) the simultaneous relationship between self efficacy and parent social support with self regulated learning. This research used a quantitative method with correlative descriptive type. The population in this research was the students at SMP Negeri 29 Padang many as 522 students. The sample in this research was many as 213 students who selected with a proportional stratified random sampling technique. The instrument was a Likert scale model. The results of instrument reliability test showed that self efficacy was much as 0.851, parent social support 0.946 and self regulated learning 0.860. The data were analyzed by using descriptive statistic, simple regression, and multiple regression. This discover research show: (1) students self efficacy was at high category, (2) students parent social support was at high category, (3) students self regulated learning was at high category, (4) there was a positive and significant relationship between of self efficacy to self regulated learning, (5) there wasa positive and significant relationship between of parent social support to self regulated learning, and (6) there wasa positive and significant simultaneous relationship between of self efficacy and parent social support with self regulated learning. Implications of these results could be used as suggestion to arrange programs of guidance and counseling service at the school.
\end{abstract}

Keyword: Self Efficacy, Parent Social Support, Self Regulated Learning

\section{PENDAHULUAN}

Pendidikan merupakan salah satu aspek yang tidak dapat dipisahkan dari kehidupan sehari-hari yang dijalani oleh manusia.Pendidikan pada hakekatnya bertujuan untuk mengembangkan potensi diri siswa agar memiliki kekuatan spiritual keagamaan, pengendalian diri, kepribadian, kecerdasan, akhlak mulia dan keterampilan.Dalam mengembangkan potensi siswa banyak pihak yang terlibat, salah satunya adalah Guru BK/Konselor.Guru BK/Konselor memiliki peranan yang sangat penting dalam meningkatkan kompetensi siswa khususnya dalam bidang belajar. Selain itu, siswa juga memberikan peranan yang penting dalam proses pembelajaran 
sehingga siswa memiliki kompetensi yang baik dalam belajar dan akan memperoleh hasil belajar yang optimal sesuai dengan harapannya. Salah satu cara meningkatkan kompetensi belajar siswa adalah dengan meregulasi diri dalam belajar atau yang sering disebut dengan self regulated learning.

Self regulated learning merupakan kemampuan seseorang untuk mengelola secara efektif pengalaman belajarnya sendiri dalam berbagai cara sehingga mendapatkan hasil belajar yang optimal ${ }^{1}$. Pintrich dalam Schunk, 2005:85) menjelaskan bahwa self regulated learning is an active, constructive process whereby learners set goals for their learning and then attempt to monitor, regulate, and control their cognition, motivation, and behavior, guided and constrained by their goals and the contextual featured in the environment ${ }^{2}$. Artinya bahwa self regulated learning merupakan sebuah prosesyang dilakukan oleh siswa, dengan menetapkan tujuan untuk pembelajarannya dan kemudian siswa akan berusaha untuk memonitor, mengatur, dan mengendalikan kognisi, motivasi perilakunya sendiri untuk mencapai tujuan yang telah dibuatnya.

Self regulated learning dibutuhkan siswa dalam proses belajar agar mereka mampu mengatur dan mengarahkan dirinya sendiri, menyesuaikan dan mengendalikan diri, terutama dalam menghadapi tugas-tugas yang sulit. Siswa juga mampu mengintegrasikan masa lalu dengan tantangan di masa kini dan mendatang serta mampu membuat rencana dengan baik untuk masa depan ${ }^{3}$. Self regulated learning dilakukan oleh siswa sebagai alat atau perantara dalam mencapai tujuan belajar yaitu memperoleh prestasi yang baik. Hal ini sejalan dengan pendapat Broson dalam Ormrod yang mengemukakan bahwa seseorang yang memiliki self regulated learning yang baik akan cenderung memiliki prestasi yang baik ${ }^{4}$. Susanto menjelaskan bahwa keberhasilan seorang anak dalam menjalani proses pendidikannya bukanlah ditentukan oleh IQ (Intelegence Quotient) semata. Ada banyak faktor yang mempengaruhi

\footnotetext{
${ }^{1}$ Wolters, dan Christopher, A. 1998."Self Regulated Learning and College Students Regulation of Motivation". Journal of Educational Psychology, 90 (2): 224-235.

2 Schunk, H. D. 2005. "Self Regulated Learning:The educational legacy of Paul R. Pintrich". Educational Psychologist, 40 (2): 85-94.

${ }^{3}$ Papalia, D. E. 2008. Human Development: Psikologi perkembangan. Terjemahan oleh A. K. Anwar. Jakarta: Kencana.

${ }^{4}$ Ormrod, J. E. 2004. Human Learning (4th Edition). Ohio: Pearson.
} 
keberhasilan seseorang dalam menjalani proses pendidikannya, salah satunya adalah kemampuan self regulation ${ }^{5}$.

Fenomena yang terjadi ditemukan data yang bervariasi yang menunjukkan bahwa masih banyak siswa yang tidak mampu mengelola self regulated learning dalam proses belajarnya dengan baik. Siswa tidak mampu untuk merencanakan kegiatan belajarnya dengan baik, siswa tidak mampu mengontrol waktu sehingga jadwal belajar tidak teratur, siswa tidak memiliki usaha untuk menyelesaikan tugas, siswa tidak mengetahui cara menciptakan lingkungan belajar yang baik dan menyenangkan, siswa tidak disiplin, siswa juga tidak tahu cara merencanakan sesuatu untuk mencapai tujuan, kurang memanfaatkan fasilitas perpustakaan, dan mengerjakan tugas mata pelajaran lain saat pelajaran lainnya sedang berlangsung.

Zimmerman juga menjelaskan bahwa many times students have difficulty completing homework assignments because there are other more interesting things they would rather do such as watching TV, day dreaming, or talking to friend ${ }^{6}$. Artinya, banyak siswa yang tidak menggunakan waktunya untuk menyelesaikan pekerjaan rumahnya dan belajar karena sibuk dengan banyak hal seperti menonton TV, bermain gadget, menghayal atau berbincang-bincang dengan temannya. Menurut Zimmerman self regulated learning dipengaruhi oleh beberapa faktor salah satu diantaranya adalah self efficacy. Self efficacy adalah persepsi tentang kemampuan untuk mengorganisasikan dan melaksanakan tindakan yang penting untuk mencapai performa yang diharapkan dalam suatu tugas tertentu ${ }^{7}$. Bandura dalam Sarafino menjelaskan bahwa self efficacy yang dimiliki oleh individu dapat membuatnya mampu menghadapi berbagai situasi ${ }^{8}$.

Bandura menjelaskan bahwa people with high assurance in their capabilities approach difficult tasks as challenges to be mastered rather than as threats to be avoided. Such an efficacious outlook fosters intrinsic interest and deep engrossment in activities. They set themselves challenging goals and maintain strong commitment to

\footnotetext{
${ }^{5}$ Susanto, H. 2006. "Mengembangkan Kemampuan Self Regulation untuk Meningkatkan Keberhasilan Akademik Siswa". Jurnal Pendidikan Penabur, 5 (7): 64-71.

6 Zimmerman, B. J. 1989. "A Social Cognitive View of Self-Regulated Academic Learning".Journal of Educational Psychology, 81 (3): 329-339.

${ }_{7}$ Ibid, Zimmerman: 337

${ }^{8}$ Sarafino, E. P., dan Smith, T. W. 2011. Health Psychology Biopsychosocial Interactions. Seventh Edition. Hoboken: Wiley. Hal 24
} 
them $^{9}$. Artinya individu yang memiliki self efficacy yang tinggi percaya dengan kemampuannya dalam menghadapi tugas yang sulit dan menantang untuk dipecahkan daripada dihindari, membuat dirinya menjadi tertantang dan berkomitmen dalam menghadapi kesulitan.

Berdasarkan pendapat tersebut, jelaslah bahwa banyak faktor yang mempengaruhiself regulated learning, dua diantaranya adalah self efficacy dan dukungan sosial orangtua. Namun, untuk mengetahui seberapa besar hubungan kedua faktor tersebut (self efficacy dan dukungan sosial orangtua) dengan self regulated learningperlu dilakukan penelitian.

Tujuan penelitian ini adalah untuk: (1) mendeskripsikan self efficacy siswa SMP Negeri 29 Padang,(2) mendeskripsikan dukungan sosial orangtua siswa SMP Negeri 29 Padang, (3) mendeskripsikan self regulated learning siswa SMP Negeri 29 Padang, (4) menguji hubungan antara self efficacy dengan self regulated learning siswa SMP Negeri 29 Padang, (5) menguji hubungan antara dukungan sosial orangtua dengan self regulated learning siswa SMP Negeri 29 Padang, dan (6) menguji hubungan antara self efficacy dan dukungan sosial orangtua secara bersama-sama dengan self regulated learning siswa SMP Negeri 29 Padang.

\section{METODOLOGI}

Penelitian ini menggunakan metode kuantitatif jenis deskriptif korelasional. Populasi penelitian adalah siswa kelas VII dan VIII SMP Negeri 29 Padang yang berjumlah 522 siswa dengan sampel 226 siswa yang dipilih dengan teknik proportional stratified random sampling. Instrumen yang digunakan adalah skala model Likert. Untuk mengetahui hubungan antara variabel bebas dengan variabel terikat, maka data dianalisis dengan regresi sederhana dan regresi ganda.Analisis dibantu dengan menggunakan program SPSS versi 20.0.

\section{HASIL PENELITIAN}

\section{Deskripsi Data}

Data dalam penelitian ini meliputi variabel self efficacy $\left(\mathrm{X}_{1}\right)$, dukungan sosial orangtua $\left(\mathrm{X}_{2}\right)$, dan self regulated learning $(\mathrm{Y})$. Berikut ini dikemukakan deskripsi data hasil penelitian.

\footnotetext{
${ }^{9}$ Bandura, A. 1994. Self Efficacy Encyclopedia of Human Behavior.New York: Academic Press.
} 


\section{Self Efficacy $\left(\mathbf{X}_{1}\right)$}

Hasil pengumpulan dan pengolahan data melalui instrumenself efficacy dari keseluruhan responden berjumlah 213 siswa dapat dilihat pada Tabel 1.

Tabel 1.Deskripsi Rata-rata (Mean) dan Persentase (\%) Self Efficacy $\left(\mathbf{X}_{1}\right)$

\section{Berdasarkan Indikator}

\begin{tabular}{|c|c|c|c|c|c|c|c|c|c|}
\hline \multirow{2}{*}{ No } & \multirow{2}{*}{ Indilsator } & \multicolumn{8}{|c|}{ SKOK } \\
\hline & & Ideal & $\operatorname{Max}$ & Mirz & $\Sigma$ & Mear & $\%$ & Sd & Ket \\
\hline 1 & $\begin{array}{l}\text { Keyakinan } \\
\text { individu dalam } \\
\text { mengeriakan } \\
\text { tugas sesuai } \\
\text { dengan tingkat } \\
\text { kesulitan }(7)\end{array}$ & 35 & 30 & 15 & 4727 & 22,19 & $63=41$ & 2,76 & $\mathrm{~s}$ \\
\hline 2 & $\begin{array}{l}\text { Kekuatan } \\
\text { keyakinan } \\
\text { dalam bentuk } \\
\text { tindakan untuk } \\
\text { mencapai hasil } \\
\text { yang diharapkan } \\
\text { (12) }\end{array}$ & 60 & 57 & 28 & 9643 & 45,27 & 75,45 & 4.85 & $T$ \\
\hline 3 & $\begin{array}{l}\text { Keyakinan atas } \\
\text { kemampuandiri } \\
\text { untuk } \\
\text { menguasai } \\
\text { berbagai bidang } \\
\text { dalam } \\
\text { menyelesaikan } \\
\text { tugas (5) }\end{array}$ & 25 & 25 & 13 & 4074 & 19,12 & 76,51 & 2,19 & $T$ \\
\hline & Keseluruhan & 120 & 104 & 61 & 18444 & 86,59 & 72,16 & 7,82 & $\mathbf{T}$ \\
\hline
\end{tabular}

Tabel 1 memperlihatkan bahwa rata-rata dari keseluruhan indikator self efficacysiswa berada pada kategori tinggi dengan persentase sebesar $72,16 \%$ dari skor ideal. Artinya bahwa self efficacy siswa dari keseluruha indikator sudah baik. Namun masih ada salah satu indikator yang berada pada kategori sedang yaitu indikator keyakinan individu dalam mengerjakan tugas sesuai dengan tingkat kesulitan yang berarti bahwa perlu adanya usaha dari siswa untuk meningkatkan keyakinannya dalam mengerjakan tugas yang sesuai dengan tingkat kesulitan.

\section{Dukungan Sosial Orangtua $\left(\mathbf{X}_{2}\right)$}

Hasil pengumpulan dan pengolahan data melalui instrumen dukungan sosial orangtua dari keseluruhan responden berjumlah 213 siswa, dapat dilihat pada Tabel 2.

\section{Tabel 2.Deskripsi Rata-rata (Mean) dan Persentase (\%) Dukungan Sosial}

\section{Orangtua $\left(\mathbf{X}_{2}\right)$ Berdasarkan Indikator}

\begin{tabular}{|c|c|c|c|c|c|c|c|c|c|}
\hline No & Indikator & Tdea & Max & Min & $=$ & Kran & 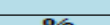 & So & Kat \\
\hline 1 & $\begin{array}{l}\text { Ungkapan } \\
\text { empati orangtua } \\
\text { (3) }\end{array}$ & 15 & 15 & 3 & 2246 & $10=54$ & 70,29 & 3,15 & $\mathbf{T}$ \\
\hline 2 & $\begin{array}{l}\text { Kepedulian } \\
\text { orangtua (3) }\end{array}$ & 15 & 15 & 7 & 2381 & 11,18 & 74.52 & 1,86 & $\mathbf{T}$ \\
\hline 3 & $\begin{array}{l}\text { Perhatian } \\
\text { orangtua (4) }\end{array}$ & 20 & 20 & 8 & 3323 & 15,60 & 78 & 2,37 & $\mathbf{T}$ \\
\hline 4 & $\begin{array}{l}\text { Dorongan untuk } \\
\text { maju (3) }\end{array}$ & 15 & 15 & 9 & 2639 & 12,39 & 82.59 & 1.66 & $\mathbf{T}$ \\
\hline 5 & $\begin{array}{l}\text { Pemberian } \\
\text { penilaian positif } \\
\text { dari orangtua } \\
\text { (2) }\end{array}$ & 10 & 10 & 5 & 1725 & 8.09 & 80,99 & $1=40$ & $\mathbf{T}$ \\
\hline 6 & $\begin{array}{l}\text { Sarana dan } \\
\text { prasarana } \\
\text { belajar (4) }\end{array}$ & 20 & 20 & 9 & 3236 & $15=19$ & 75,96 & 2,12 & $\mathbf{T}$ \\
\hline 7 & $\begin{array}{l}\text { Bantuan berupa } \\
\text { iasa }(2)\end{array}$ & 10 & 10 & 4 & 1644 & 7,71 & $77=18$ & 1,32 & $\mathbf{T}$ \\
\hline 8 & Nasehat (2) & 10 & 10 & 2 & 1737 & 8,15 & 81.55 & 1,44 & $T$ \\
\hline
\end{tabular}


Tabel 2 memperlihatkan bahwa rata-rata dari keseluran indikator dukungan sosial orangtua siswa berada pada kategori tinggi dengan persentase sebesar 78,09\% dari skor ideal. Dukungan sosial orangtua yang diterima siswa baik dalam bentuk perhatian, empati, kepedulian orangtua, memberikan sarana dan prasarana yang baik, bantuan berupa jasa, nasehat, saran maupun petunjuk akan membuat siswa merasa dirinya didukung, disokong, dan dimotivasi oleh orang terdekat dalam mengembangkan potensi dirinya.

\section{Self Regulated Learning $(\mathbf{Y})$}

Hasil pengumpulan dan pengolahan data melalui instrumen self regulated learning dari keseluruhan responden berjumlah 213 siswa, dapat dilihat pada Tabel 3.

Tabel 3. Deskripsi Rata-rata (Mean) dan Persentase (\%) Self Regulated

\section{Learning $(\mathrm{Y})$ Berdasarkan Indikator}

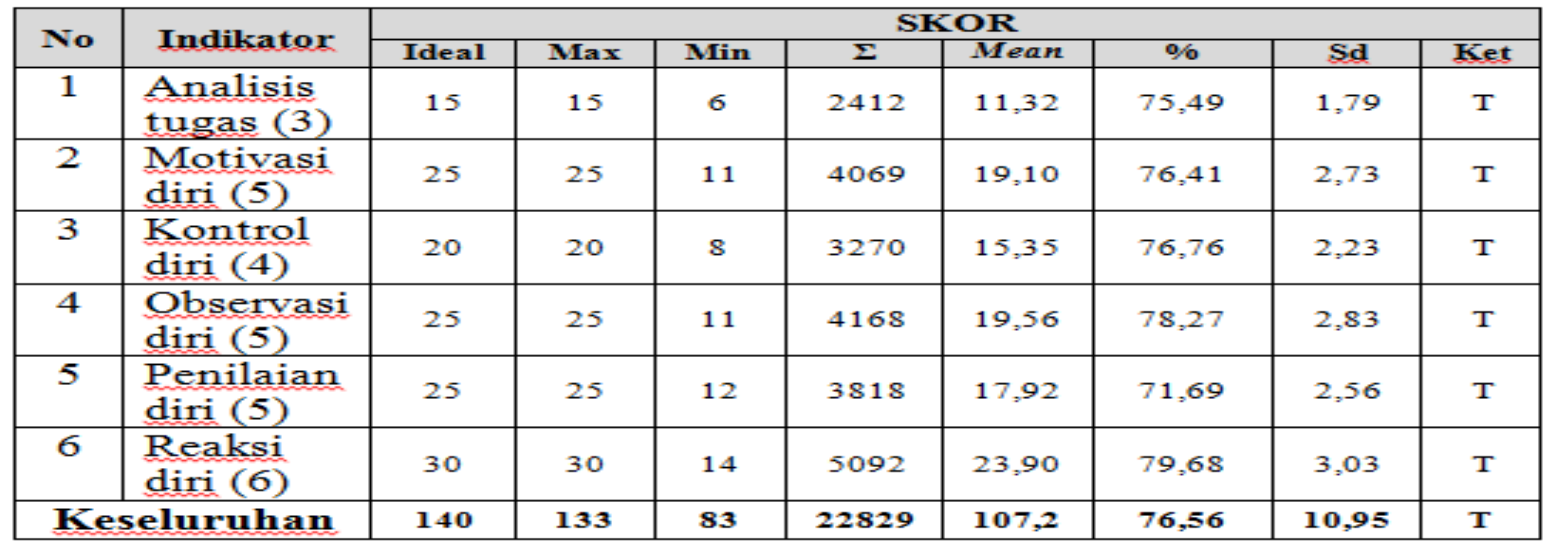

Tabel 3 memperlihatkan bahwa rata-rata dari keseluruhan indikator self regulated learning siswaberada pada kategori tinggi dengan persentase sebesar 76,56\% dari skor ideal. Artinya bahwa self regulated learning siswa sudah baik, namun perlu adanya peningkatan yang lebih baik lagi dari masing-masing indikator self regulated learning sehingga pencapaian self regulated learning siswa akan menjadi lebih optimal.

\section{Pengujian Persyaratan Analisis Data}


Uji persyaratan analisis yang dilakukan pada data penelitian ini adalah uji normalitas, uji linieritas, dan uji multikolinieritas.

\section{a) Uji Normalitas}

Pengujian normalitas dilakukan dengan menggunakan metode KolmogorovSmirnov.Jika Asymp. Sig. atau P-value >0,05 (taraf signifikansi), maka data berasal dari populasi yang berdistribusi normal ${ }^{10}$. Hasil uji normalitas data nilai Asymp. Sig.self efficacy sebesar0,177, dukungan sosial orangtua sebesar 0,322, dan self regulated learning sebesar 0,282. Berarti ketiga data variabel penelitianberdistribusi normal.

\section{b) Uji Linieritas}

Uji linieritas dalam penelitian ini menggunakan bantuan program SPSS versi 20.0. Jika nilai $F_{\text {hitung }}>F_{\text {tabel, }}$, maka dinyatakan linier, dan sebaliknya jika nilai $F_{\text {hitung }}<$ $\mathrm{F}_{\text {tabel}}$,maka dinyatakan tidak linier ${ }^{11}$. Berdasarkan hasil uji linieritas, didapatkan hasil bahwa hubungan self efficacy dengan self regulated learningadalah linier dengan $\mathrm{F}_{\text {hitung }}$ $61,912>\mathrm{F}_{\text {tabel }} 3,89$. Data hubungan dukungan sosial orangtua dengan self regulated learning juga linier dengan $\mathrm{F}_{\text {hitung }} 17,643>\mathrm{F}_{\text {tabel }} 3,89$.

\section{c) Uji Multikolinieritas}

Berdasarkan uji multikolinieritas, diperoleh nilai VIF sebesar 1,014. Nilai $1,014<5$. Berdasarkan hasil tersebut dapat disimpulkan tidak terjadi multikolinieritas antara variabel self efficacy dengan dukungan sosial orangtua.

\section{Pengujian Hipotesis Penelitian}

a) Hubungan Self Efficacy dengan Self Regulated Learning

Hasil analisishubungan self efficacy dengan self regulated learningpada Tabel 4.

Tabel 4. Hasil Analisis Regresi Sederhana dan Uji Signifikansi $X_{1}$ terhadap $Y$

\begin{tabular}{|l|r|l|c|}
\hline Model & $\mathbf{R}$ & R Square & Sig. \\
\hline $\mathrm{X}_{1}-\mathrm{Y}$ & 0,483 & 0,233 & 0,000 \\
\hline
\end{tabular}

Tabel 4 di atas memperlihatkan bahwa nilai $\mathrm{R}$ sebesar 0,483 menunjukkan koefisien korelasi antara self efficacy dengan self regulated learning, dengan taraf

\footnotetext{
${ }^{10}$ Widiyanto, M. A. 2013. Statistika Terapan: Konsep \& aplikasi SPSS/LISREL dalam penelitian pendidikan, psikologi \& ilmu sosial lainya. Jakarta: Kompas Gramedia.

11 Yusuf, A. M. 2013. Metode Penelitian Kuantitatif, Kualitatif dan Penelitian Gabungan. Padang: UNP Press. Hal 290
} 
signifikansi 0,000. Artinya, terdapat hubungan yang positif dan signifikan antara self efficacy dengan self regulated learning. Nilai $\mathrm{R}$ Square $\left(\mathrm{R}^{2}\right)$ sebesar 0,233, ini berarti 23,3\% variasi pada self regulated learning dapat dijelaskan oleh self efficacy, sedangkan sisanya 76,7\% dijelaskan oleh variabel lain.

\section{b) Hubungan Dukungan Sosial Orangtua dengan Self Regulated Learning}

Hasil analisishubungan dukungan sosial orangtua dengan self regulated learning dapat dilihat pada Tabel 5.

Tabel 5. Hasil Analisis Regresi Sederhana dan Uji Signifikansi $X_{2}$ terhadap Y

\begin{tabular}{|l|l|l|c|}
\hline Model & \multicolumn{1}{|c|}{$\mathbf{R}$} & \multicolumn{1}{c|}{ S Square } & Sig. \\
\hline $\mathrm{X}_{2}-\mathrm{Y}$ & 0,289 & 0,083 & 0,000 \\
\hline
\end{tabular}

Tabel 5 di atas memperlihatkan bahwa nilai $\mathrm{R}$ sebesar 0,289 menunjukkan koefisien korelasi antara dukungan sosial orangtua dengan self regulated learning, dengan taraf signifikansi 0,000. Artinya terdapat hubungan yang positif dan signifikan antara dukungan sosial orangtua dengan self regulated learning. Nilai R Square $\left(\mathrm{R}^{2}\right)$ sebesar 0,083, ini berarti 8,3\% variasi pada self regulated learning dapat dijelaskan oleh dukungan sosial orangtua, sedangkan sisanya 91,7\% dijelaskan oleh variabel lain.

c) Hubungan self efficacy dan dukungan sosial orangtua dengan self regulated learning

Hasil analisis hubungan dukungan sosial orangtua dengan self regulated learning dapat dilihat pada Tabel 6.

Tabel 6.Hasil Analisis Regresi Ganda dan Uji Signifikansi $X_{1}$ dan $X_{2}$ terhadap $Y$

\begin{tabular}{|c|c|l|c|}
\hline Model & \multicolumn{1}{|c|}{$\mathbf{R}$ Square } & Sig. \\
\hline $\mathrm{X}_{1}, \mathrm{X}_{2}-\mathrm{Y}$ & 0,536 & 0,287 & 0,000 \\
\hline
\end{tabular}

Pada Tabel 6 di atas memperlihatkan bahwa nilai $\mathrm{R}$ sebesar 0,536 yang menunjukkan koefisien regresi ganda antara self efficacy dan dukungan sosial orangtua dengan self regulated learning, dengan taraf signifikansi 0,000. Artinya, terdapat hubungan yang positif dan signifikan antara self efficacy dan dukungan sosial orangtua secara bersama-sama dengan self regulated learning. Nilai $\mathrm{R}$ Square $\left(\mathrm{R}^{2}\right)$ sebesar 0,287, ini berarti $28,7 \%$ variasi pada self regulated learning dapat dijelaskan secara bersama-sama oleh self efficacy dan dukungan sosial orangtua, sedangkan sisanya $71,3 \%$ dijelaskan oleh variabel lain. 


\section{PEMBAHASAN}

\section{Self Efficacy}

Hasil analisis data penelitian menunjukkan bahwa secara keseluruhan self efficacy siswa berada pada kategori tinggi dengan rata-rata persentase sebesar 79,89\% dari skor ideal. Berdasarkan pencapaian masing-masing indikator self efficacy, yaitu: indikator keyakinan dalam mengerjakan tugas sesuai dengan tingkat kesulitan, kekuatan keyakinan dalam bentuk tindakan untuk mencapai hasil yang diharapkan, dan keyakinan atas kemampuan diri untuk menguasai berbagai bidang dalam menyelesaikan tugas berada pada kategori tinggi. Menurut Bandura dan Woods dalam Ghufron self efficacy mengacu pada keyakinan akan kemampuan individu untuk menggerakkan motivasi, kemampuan kognitif dan tindakan yang diperlukan untuk memenuhi tuntutan situasi di masa yang akan datang. Individu yang memiliki self efficacy tinggi akan yakin pada dirinya bahwa dengan kemampuannya dapat memecahkan tugas yang sulit sekalipun dan menyesuaikan dengan tingkat kesulitan tugas yang disesuaikan dengan kemampuannya ${ }^{12}$. Bandura mengemukakan bahwa self efficacy juga akan mempengaruhi pemilihan tugas, usaha, ketekunan, ketahanan, dan prestasi seseorang $^{13}$.

Seseorang yang memiliki self efficacy yang tinggi akan mencapai hasil belajar yang optimal sesuai dengan apa yang diharapkannya. Hal ini senada dengan pendapat Pajares dan Urdan yang menyatakan individu yang memiliki self efficacy yang tinggi akan lebih mudah melakukan pengaturan diri dalam belajar, dan menciptakan lingkungan yang efektif untuk belajar dalam rangka mendorong ketercapaian hasil belajar yang maksimal ${ }^{14}$. Berbagai usaha dan cara yang harus dilakukan oleh siswa untuk meningkatkan self efficacy. Elfiky menyatakan bahwa cara untuk meningkatkan self efficacy seseorang adalah dengan cara pelatihan berpikir positif yang menekankan pada sudut pandang dan emosi yang positif baik terhadap diri sendiri, orang lain maupun situasi yang dihadapi ${ }^{15}$.

\footnotetext{
${ }^{12}$ Bandura, A. 1994. Self Efficacy Encyclopedia of Human Behavior.New York: Academic Press. Hal 74

${ }^{13}$ Bandura, A. 1997. Self Efficacy: The exercise of control. New York: Freeman. Hal 24

14 Pajares, F., dan Urdan, T. 2006. Self Efficacy Beliefs of Adolescents. Connecticut: Information Age Publishing. Hal 36

${ }^{15}$ Elfiky, I. 2008. Terapi Berpikir Positif. Jakarta: Kalola Printing. Hal 26
} 
Berdasarkan hasil penelitian, tindakan yang dapat dilakukan untuk meningkatkan self efficacy siswa dapat dilakukan melalui layanan bimbingan dan konseling.Guru BK/Konselor dapat memberikan pengaruh yang baik dan positif yang dapat memfasilitasi siswa dalam memenuhi tugas-tugas perkembangan dengan optimal. Salah satu layanan yang dapat digunakan adalah layanan konseling kelompok. Sesuai dengan konsepnya bahwa self efficacy dapat ditingkatkan melalui layanan konseling kelompok. Penelitian Setiawan menunjukkan bahwa model konseling kelompok dengan teknik problem solving efektif untuk meningkatkanself efficacy siswa. Berdasarkan penjelasan tersebut, dapat dimaknai bahwa layanan konseling kelompok merupakan salah satu alternatif yang dapat meningkatkan self efficacy $\operatorname{siswa}^{16}$.

\section{Dukungan Sosial Orangtua}

Hasil analisis data penelitian menunjukkan bahwa secara keseluruhan dukungan sosial orangtua yang diterima siswa berada pada kategori tinggi dengan ratarata persentase sebesar $67,60 \%$ dari skor ideal.

Berdasarkan pencapaian masing-masing indikator dari variabel dukungan sosial orangtua, yaitu: ungkapan empati orangtua, kepedulian orangtua, perhatian orangtua, dorongan untuk maju, pemberian penilaian positif dari orangtua, sarana dan prasarana belajar, bantuan berupa jasa, nasehat dan saran berada pada kategori tinggi sedangkan untuk indikator petunjuk berada pada kategori sangat tinggi. Farmer dan Farmer dalam Pavri dan Monda mendefinisikan dukungan sosial sebagai sebuah proses pertukaran sosial yang menyumbangkan perkembangan pola perilaku seseorang, kesadaran sosial serta nilai ${ }^{17}$. Effendi dan Tjahyono menyatakan bahwa dukungan sosial merupakan transaksi interpersonal yang diajukan dengan memberikan bantuan kepada individu lain dan bantuan itu diperoleh dari orang yang berarti bagi individu yang bersangkutan ${ }^{18}$.

Orangtua sebagai seseorang yang memiliki kedekatan psikologis kepada anak menjadi kewajibannya untuk memberikan dorongan untuk kemajuan anaknya terutama kemajuan dalam kegiatan belajar anak di sekolah, sehingga anak akan merasa dirinya

${ }^{16}$ Setiawan, M. A. 2015. "Model Konseling Kelompok dengan Teknik Problem Solving untuk Meningkatkan Self Efficacy Akademik Siswa".Jurnal Bimbingan Konseling, 4 (1):8-14.

${ }^{17}$ Pavri, S dan Monda, A. L. 2001, "Social Support in Inclusive Schools: Student and teacher perspectives". Journal of Educational Psychology, 67 (3): 391-411.

18 Effendi., dan Tjahyono. 1999. "Hubungan antara Perilaku Coping dan Dukungan Sosial dengan Kecemasan pada Ibu Hamil Anak Pertama Anima”. Journal, (54): 214-227. 
didukung sepenuhnya oleh orangtuanya. Slameto menyatakan bahwa salah satu faktor yang terkandung dalam dukungan orangtua adalah pengertian orangtua di mana anak perlu dorongan dari orangtua ${ }^{19}$. Kegiatan belajar anak perlu mendapatkan dorongan dari orangtua dan pengertian dari orangtua. Kadang-kadang anak mengalami penurunan semangat, maka orangtua wajib memberi pengertian dan mendorongnya, membantu sedapat mungkin kesulitan yang dialami anak baik di sekolah maupun di masyarakat.

Tindakan yang dapat dilakukan untuk meningkatkan dukungan sosial orangtua yang diterima siswa dapat dilakukan melalui layanan bimbingan dan konseling. Guru BK/Konselor dapat memberikan pengaruh yang baik dan positif yang dapat memfasilitasi siswa dalam memenuhi tugas-tugas perkembangan dengan optimal. Salah satu layanan yang dapat digunakan adalah layanan informasi dengan berbagai materi yang terkait dengan dukungan sosial orangtua seperti; (a) peran orangtua, (b) komunikasi yang efektif kepada orangtua.

\section{Self Regulated Learning}

Hasil analisis data penelitian menunjukkan bahwa secara keseluruhan dukungan sosial orangtua yang diterima siswa berada pada kategori tinggi dengan ratarata persentase sebesar 68,08\% dari skor ideal. Pintrich dalam Schunk menyatakan bahwa self regulated learning adalah suatu proses yang dilakukan oleh siswa, dengan menetapkan tujuan untuk pembelajarannya dan kemudian siswa akan berusaha untuk memonitor, mengatur, dan mengendalikan kognisi, motivasi perilakunya sendiri untuk mencapai tujuan yang telah dibuatnya ${ }^{20}$.

Berdasarkan pencapaian masing-masing indikator dari variabel self regulated learning, yaitu: analisis tugas, motivasi diri, kontrol diri, observasi diri, penilaian diri, dan reaksi diri berada pada kategori tinggi. Siswa yang memiliki self regulated learning yang tinggi akan mengetahui sasaran belajarnya, strategi apa yang akan ditetapkan untuk menyelesaikan tugas akademik dan dapat memantau kemajuan diri sendiri. Zimmerman menjelaskan bahwa salah satu dari strategi self regulated learning adalah penetapan tujuan dan perencanaan serta pencarian informasi yang mengindikasikan bahwa siswa berinisiatif untuk mendapatkan informasi berkenaan dengan tugas selanjutnya dari sumber-sumber yang ada ketika mengerjakan

\footnotetext{
${ }^{19}$ Slameto. 2003. Belajar dan Faktor-faktor yang Mempengaruhinya. Jakarta: Rineka Cipta.

20 Schunk, H. D. 2005. "Self Regulated Learning:The educational legacy of Paul R. Pintrich".Educational Psychologist, 40 (2): 85-94.
} 
tugas.Berdasarkan hasil temuan ini, maka perlu kiranya untuk meningkatkan self regulated learning siswa $^{21}$.

Guru BK/Konselor sebagai penyelenggara pelayanan bimbingan dan konseling di sekolah dapat menyusun program layanan yang dapat dilaksanakan terkait dengan peningkatan self regulated learning siswa. Hal yang dapat dilakukan oleh Guru $\mathrm{BK} /$ Konselor untuk meningkatkan self regulated learning siswa adalah dengan cara memberikan layanan bimbingan dan konseling, yaitu (a) layanan informasi, misalnya dengan materi pemanfaatan sumber belajar, evaluasi hasil belajar, disiplin belajar, dan kunci sukses menghadapi ujian, (b) layanan penguasaan konten, misalnya dengan manajemen waktu, mind mapping, dan keterampilan mengikuti ujian.

\section{Hubungan Self Efficacy dengan Self Regulated Learning}

Hasil penelitian ini membuktikan bahwa terdapat hubungan yang signifikan antara self efficacy dengan self regulated learning. Temuan ini diperoleh berdasarkan hasil analisis data yang menunjukkan bahwa hubungan self efficacy dengan self regulated learning sebesar 23,3\%. Arah hubungan self efficacy dan self regulated learning positif yang berarti bahwa semakin tinggi self efficacy siswa, maka semakin tinggi pula self regulated learning siswa.Boufart, Parent, dan Larrivee dalam Warsito menyatakan bahwa siswa yang memiliki self efficacy tinggi dan sukses dalam memecahkan masalah tampak kinerjanya lebih besar dan tetap bertahan lama dibandingkan dengan siswa yang memiliki self efficacy yang lebih rendah ${ }^{22}$. Schunk menyatakan bahwa kesuksesan yang tertunda atau kemajuan yang lamban tidak menurunkan self efficacy jika siswa merasa yakin bahwa mereka mampu melakukan sesuatu lebih baik dengan berusaha lebih keras atau menggunakan strategi yang lebih efektif $^{23}$. Strategi tersebut dapat dilakukan jika siswa memiliki self regulated learning yang baik, karena siswa yang memiliki self regulated learning yang baik akan membuat strategi-strategi yang jitu untuk mencapai hasil yang optimal.

Penggunaan strategi yang efektif dan efisien dalam mencapai tujuan yang diharapkan menunjukkan adanya kecakapan untuk mengatur kemampuan dan waktu yang dimiliki. Hasil penelitian Larrivee membuktikan bahwa siswa dengan self

21 Zimmerman, B. J. 1989. "A Social Cognitive View of Self-Regulated Academic Learning".Journal of Educational Psychology, 81 (3): 337.

${ }^{22}$ Warsito, H. 2009. "Hubungan antara Self Efficacy dengan Penyesuaian Akademik dan Prestasi Akademik". Jurnal Ilmiah Ilmu Pendidikan Pedagogi, 9 (1): 29-46.

${ }^{23}$ Schunk, H. D. 2005. "Self Regulated Learning:The educational legacy of Paul R. Pintrich". Educational Psychologist, 40 (2): 85-94. 
efficacy tinggi menggunakan strategi pengaturan diri (self regulation) yang lebih efektif terhadap kemampuan yang dimilikinya ${ }^{24}$.

Menurut Bandura dalam Prakosa ada beberapa upaya yang dilakukan untuk meningkatkan self efficacy dalam proses pembelajaran, yaitu:(1) performance accomplishment adalah keberhasilan yang dicapai oleh seseorang berdampak pada keyakinan diri (self efficacy) yang semakin kuat, (2) vicarious experience, dengan mengamati orang lain mampu melakukan suatu aktivitas dalam situasi yang menekan tanpa mengalami akibat yang merugikan sehingga menumbuhkan pengharapan bagi pengamat, maka akan timbul keyakinan bahwa nantinya individu juga akan berhasil jika berusaha secara intensif dan tekun. Mereka mensugesti diri bahwa jika orang lain dapat melakukan, tentu mereka juga dapat berhasil setidaknya dengan sedikit perbaikan dalam performansi, (3) verbal persuasion, seseorang yang diarahkan melalui sugesti dan bujukan untuk percaya bahwa mereka dapat mengatasi masalah-masalah di masa yang akan datang, dan (4) emotional arousal, dalam situasi yang menekan, kondisi emosional dapat mempengaruhi pengharapan self efficacy seseorang ${ }^{25}$.

\section{Hubungan Dukungan Sosial Orangtua dengan Self Regulated Learning}

Hasil analisis membuktikan bahwa terdapat hubungan yang signifikan antara dukungan sosial orangtua dengan self regulated learning. Temuan ini diperoleh berdasarkan hasil analisis data yang menunjukkan bahwa hubungan dukungan sosial orangtua terhadap self regulated learning sebesar 8,3\%. Artinya, semakin tinggi dukungan sosial orangtua yang diterima siswa maka semakin tinggi pula self regulated learning yang dilakukan oleh siswa dan sebaliknya, semakin rendah dukungan sosial orangtua yang diterima siswa maka semakin rendah pula self regulated learning yang dilakukan oleh siswa.

Gottlieb dalam Smet menyatakan bahwa dukungan sosial terdiri dari informasi atau nasehat verbal dan non-verbal, bantuan nyata ataupun tindakan yang diberikan oleh keakraban sosial atau didapat karena kehadiran orang yang mendukung serta hal ini mempunyai manfaat emosional atau efek perilaku penerima ${ }^{26}$. Dukungan sosial yang diterima anak dari orangtua diharapkan mampu membuat anak semangat untuk

\footnotetext{
${ }^{24}$ Larrivee, B. 2005.Aunthentic Classroom Management: Creating a learning community and buildding reflective practice (2nd ed.). Boston, USA:Pearson Education, Inc.

25 Prakosa, H. 1996. "Cara Penyampaian Hasil Belajar untuk Meningkatkan Self Efficacy Mahasiswa".Jurnal Psikologi, 2 (1): 11-12.

${ }^{26}$ Smet, B. 1994. Psikologi Kesehatan. Jakarta: Grasindo. Hal 35
} 
belajar dan meningkatkan kemampuan self regulated learningnya. Pintrich dalam Cheng menyatakan bahwa self regulated learning merujuk pada strategi yang digunakan siswa untuk mengatur kognisi dan mengelola sumber, yang berarti mengelola dan mengendalikan lingkungan. Pintrich menganggap bahwa kegiatan self regulated learning bertindak sebagai mediator antara siswa, lingkungan dan performa belajar siswa secara keseluruhan ${ }^{27}$. Adicondro dan Purnamasari dalam Situmorang dan Latifah menyatakan bahwa dukungan sosial merupakan salah satu faktor yang berhubungan dengan strategi pengaturan diri dalam belajar (self regulated learning ${ }^{28}$.

Banyak manfaat yang diterima oleh siswa ketika mendapatkan dukungan sosial dari orangtuanya. Hurlock (2011) menyatakan bahwa dukungan yang diberikan keluarga terutama orangtua yang berupa penerimaan, perhatian dan rasa percaya akan meningkatkan kebahagiaan dalam diri remaja sehingga remaja termotivasi untuk terus berusaha mencapai tujuannya.

Upaya yang dapat dilakukan Guru BK/Konselor untuk meningkatkan dukungan sosial orangtua yang diterima siswa dapat dilakukan melalui layanan bimbingan dan konseling. Guru BK/Konselor dapat memberikan pengaruh yang baik dan positif yang dapat memfasilitasi siswa dalam memenuhi tugas-tugas perkembangan dengan optimal. Salah satu layanan yang dapat digunakan adalah layanan informasi dengan berbagai materi yang terkait dengan dukungan sosial orangtua seperti; (a) peran orangtua, dan (b) komunikasi yang efektif kepada orangtua.

\section{Hubungan Self Efficacy dan Dukungan Sosial Orangtua dengan Self Regulated}

\section{Learning}

Hasil penelitian menunjukkan bahwa terdapat hubungan yang signifikan antara self efficacy dan dukungan sosial orangtua secara bersama-samadengan self regulated learning. Temuan ini diperoleh berdasarkan rangkaian analisis data yang menunjukkan bahwa sumbangan self efficacy dan dukungan sosial orangtua secara bersama-sama terhadap self regulated learning sebesar 28,7\%. Artinya, self efficacy dan dukungan sosial orangtua merupakan faktor yang berhubungan dengan self regulated learning.Berdasarkan hasil penelitian semakin tinggi self efficacy dan dukungan sosial

\footnotetext{
27 Cheng, E.C.K. 2011. "The Role of Self Regulated Learning in Enchanching Learning Performance. The International Journal of Research Riview, vol. 06.

${ }^{28}$ Situmorang, Z. R. D., dan Latifah, M. 2014. "Pengaruh Dukungan Sosial, Konsep Diri, dan Strategi Pengatura Diri dalam Belajar terhadap Prestasi Akademik.Jurnal Ilmu Keluarga dan Konsumen, 7 (3): 154-163.
} 
orangtua maka semakin tinggi self regulated learning siswa, dan begitu pula sebaliknya semakin rendah self efficacy dan dukungan sosial orangtua semakin rendah pula self regulated learning siswa.

Seperti yang telah dibahas sebelumnya, menurut Zimmerman dalam Subran faktor yang mempengaruhi self regulated learning yaitu: (1) pengaruh individu yang termasuk di dalamnya adalah self efficacy, orientasi atau tujuan, pengetahuan, proses metakognisi (perencanaan dan pemonitoran), dan kecemasan, (2) pengaruh perilaku yang termasuk di dalamnya adalah behavior self reaction, personal self reaction dan environmental self reaction, dan (3) lingkungan yang termasuk di dalamnya adalah social and enactive experience, dukungan sosial seperti dari guru, orangtua, teman, maupun berbagai bentuk informasi literature dan simbolik lainnya serta struktur konteks belajar seperti karakteristik tugas dan situasi akademik.

\section{KESIMPULAN}

Berdasarkan temuan dan pembahasan hasil penelitian, maka dapat dikemukakan kesimpulan sebagai berikut:

1. Self efficacy siswa SMP Negeri 29 Padang berada pada kategori tinggi.

2. Dukungan sosial orangtua yang diterima siswa SMP Negeri 29 Padang berada pada kategori tinggi.

3. Self regulated learning siswa SMP Negeri 29 Padang berada pada kategori tinggi.

4. Terdapat hubungan yang signifikan antara self efficacy dengan self regulated learning. Artinya apabila self efficacy ditingkatkan menjadi lebih tinggi, maka self regulated learning akan meningkat menjadi lebih tinggi, atau sebaliknya apabila self efficacy rendah, maka self regulated learning juga rendah.

5. Terdapat hubungan yang signifikan antara dukungan sosial orangtua dengan regulated learning. Artinya apabila dukungan sosial orangtua yang diterima siswa tinggi, maka self regulated learning siswa akan meningkat menjadi lebih tinggi, atau sebaliknya apabila dukungan sosial orangtua yang diterima siswa rendah, maka self regulated learning siswa rendah.

6. Terdapat hubungan yang signifikan antara self efficacy dan dukungan sosial orangtua secara bersama-sama dengan self regulated learning. Artinya, tinggi rendahnya self regulated learning tidak hanya dipengaruhi oleh satu variabel saja (self efficacy atau dukungan sosial orangtua), namun dipengaruhi secara bersama- 
sama oleh self efficacy dan dukungan sosial orangtua. Dengan kata lain dapat dikatakan bahwa semakin tinggi self efficacy dan dukungan sosial orangtua yang diterima siswa, maka semakin tinggi self regulated learning yang dilakukan oleh siswa. Hal ini berarti, variabel self efficacy dan dukungan sosial orangtua akan lebih efektif jika dikombinasikan secara bersama-sama sebagai prediktor untuk meningkatkan self regulated learning siswa.

\section{DAFTAR PUSTAKA}

Bandura, A. 1994. Self Efficacy Encyclopedia of Human Behavior.New York: Academic Press.

Bandura, A. 1997. Self Efficacy: The exercise of control. New York: Freeman.

Cheng, E.C.K. 2011. "The Role of Self Regulated Learning in Enchanching Learning Performance. The International Journal of Research Riview, vol. 06.

Effendi., dan Tjahyono. 1999. "Hubungan antara Perilaku Coping dan Dukungan Sosial dengan Kecemasan pada Ibu Hamil Anak Pertama Anima”. Journal, (54)

Elfiky, I. 2008. Terapi Berpikir Positif. Jakarta: Kalola Printing.

Ghufron, N. 2010. Teori-teori Psikologi. Yogyakarta: Ar-ruz Media.

Hurlock, E.B. 2011. Psikologi Perkembangan: Suatu pendekatan sepanjang rentang kehidupan (Edisi Kelima). Jakarta: Erlangga.

Larrivee, B. 2005.Aunthentic Classroom Management: Creating a learning community and buildding reflective practice (2nd ed.). Boston, USA:Pearson Education, Inc.

Ormrod, J. E. 2004. Human Learning (4th Edition). Ohio: Pearson.

Pajares, F., dan Urdan, T. 2006. Self Efficacy Beliefs of Adolescents. Connecticut: Information Age Publishing.

Papalia, D. E. 2008. Human Development: Psikologi perkembangan. Terjemahan oleh A. K. Anwar. Jakarta: Kencana.

Prakosa, H. 1996. "Cara Penyampaian Hasil Belajar untuk Meningkatkan Self Efficacy Mahasiswa".Jurnal Psikologi, 2 (1)

Pavri, S dan Monda, A. L. 2001, "Social Support in Inclusive Schools: Student and teacher perspectives". Journal of Educational Psychology, 67 (3)

Sarafino, E. P. 2006. Health Psychology (5th Edition). New York: John Wiley and Sons.

Sarafino, E. P., dan Smith, T. W. 2011. Health Psychology Biopsychosocial Interactions. Seventh Edition. Hoboken: Wiley.

Setiawan, M. A. 2015. "Model Konseling Kelompok dengan Teknik Problem Solving untuk Meningkatkan Self Efficacy Akademik Siswa".Jurnal Bimbingan Konseling, 4 (1)

Smet, B. 1994. Psikologi Kesehatan. Jakarta: Grasindo. 
Schunk, H. D. 2005. "Self Regulated Learning:The educational legacy of Paul R. Pintrich".Educational Psychologist, 40 (2)

Situmorang, Z. R. D., dan Latifah, M. 2014. "Pengaruh Dukungan Sosial, Konsep Diri, dan Strategi Pengatura Diri dalam Belajar terhadap Prestasi Akademik.Jurnal Ilmu Keluarga dan Konsumen, 7 (3)

Slameto. 2003. Belajar dan Faktor-faktor yang Mempengaruhinya. Jakarta: Rineka Cipta.

Susanto, H. 2006. "Mengembangkan Kemampuan Self Regulation untuk Meningkatkan Keberhasilan Akademik Siswa". Jurnal Pendidikan Penabur, 5 (7)

Warsito, H. 2009. "Hubungan antara Self Efficacy dengan Penyesuaian Akademik dan Prestasi Akademik". Jurnal Ilmiah Ilmu Pendidikan Pedagogi, 9 (1)

Wolters, dan Christopher, A. 1998."Self Regulated Learning and College Students Regulation of Motivation". Journal of Educational Psychology, 90 (2)

Widiyanto, M. A. 2013. Statistika Terapan: Konsep \& aplikasi SPSS/LISREL dalam penelitian pendidikan, psikologi \& ilmu sosial lainya. Jakarta: Kompas Gramedia.

Yusuf, A. M. 2013. Metode Penelitian Kuantitatif, Kualitatif dan Penelitian Gabungan. Padang: UNP Press.

Zimmerman, B. J. 1989. "A Social Cognitive View of Self-Regulated Academic Learning”.Journal of Educational Psychology, 81 (3) 